\title{
Social Justice Value of Pancasila in Local Finance Accountability for Economic Growth
}

\author{
D Sintara ${ }^{1}$ and Suhaidi ${ }^{2}$ \\ Law Program, Universitas Sumatera Utara, Medan, Indonesia \\ 11danisintara@yahoo.co.id
}

\begin{abstract}
In a democratic life, local finance accountability plays a pivotal role in preventing local government officials from abusing power. Thereby, one parameter in measuring a local finance accountability to be free from abuse of power is by providing justice value as stated in the fifth principle of Pancasila. Pancasila is Indonesia's life philosophy. However, the present local finance accountability fails to accommodate the justice value of Pancasila as it has been centering around political relations amongst institutions, regardless of whether it has provided justice value or not. The local finance accountability without social justice value of Pancasila fails to achieve the main objective of the regional autonomy, which consequently have an impact on the social life at the nationhood and statehood levels, and finally damages the social system of the nation. Since the local finance accountability without justice value of Pancasila has a negative impact on the administration of the local government, the mechanism for local finance accountability should give room for the society/social groups participation to check whether the local finance accountability has accommodated the justice value or not. If not, such accountability needs to be reevaluated.
\end{abstract}

Keywords: Pancasila, Accountability, Government

\section{INTRODUCTION}

Accountability must be based on the public expectation that the government will not violate the principles perceived to be right and wrong when taking an action. This opinion is in accordance with an understanding that in performing its duties, a country is adhered to ethical norms with justice value as the most fundamental aspect [1]. The justice value is the value of a social justice for the whole Indonesian people as outlined in the fifth principle of Pancasila, as the nation's life philosophy and serves as the primary source of all national law.A value will only has a meaning if it is applied to a social life where there is a human interaction or an association between the society and its leaders since such social relation brings meanings and determines the level of justice or injustice. Simply, the interaction brings about a phrase or a term of the social justice [2]. Thereby, justice becomes the basis or principle or fundamental thought of a social life.

Based on the above point, a local finance accountability report is one form of relationship between the government and the society. Therefore, justice value should be incorporated to bring social justice to the whole Indonesian people in general and to the society of the region in particular. Incorporating justice value is mainly aimed at creating a harmonious social life. 
Nonetheless, the implementation of local finance accountability is still far from the principle of justice value. There is no rule for granting the rights to society/societal groups to check whether a local finance accountability ignores justice value or notwhich then serves as a basis for reevaluation of such accountability. This owes to the fact that the local finance accountability mechanisms is still bound to the relationship amongst political institutions in the region thus it fails to provide justice for the society. Ideally, justice should be the main objective of regional autonomy as well as implementing democracy and prosperity for all the people in the Unitary State of the Republic of Indonesia.

\section{METHOD}

This is a normative legal research. The data are secondary data comprised of (a) primary legal materials such as legislations, (b) secondary legal materials such as writings, either books or articles covering commentaries or analysis related to topic of discussion, and (c) tertiary legal materials like dictionaries. Literature review and document analysis were used to collect the data. The data were analyzed using a qualitative deductive reasoning method.

\section{RESULT and DISCUSSION}

\subsection{The Meaning of Social Justice Value of Pancasila in Local Financial Accountability}

Value is a good or noble perception on what people want to benefit from in their lives. As the value is used by the society to underlie their social relations such as the relationship between the government and the citizens, therein lies the socialization of the value, which then is developed into a principle, or in other words justice value is developed into a social justice principle [3].

Therefore, the meaning of social justice in Pancasila is translated into justice applicable in the society across all spectrum of life both materially and spiritually. This means that justice is not only enjoyed by the rich but also by the poor and not only by the leaders but also by the people under their leadership [4].

In relation to the fifth principle of Pancasila, the adminstration of Local Government must embody justice values, including: The realization of social justice in the social life of the whole Indonesian people. Justice in social life mainly covers the spheres of ideology, political, economic, social, cultural and national security and defense, the goal of building a just and prosperous society, materially and spiritually equal to the whole Indonesian people, a balance between rights and responsibilities, and respect for other people's rights and have a great interest in a good progress and development [5].

Principally, local finance accountability should provide justice value to all stakeholders particularly the society considering that Pancasila is the nation's life philosophy and makes up the source of all sources of the laws.

Justice value of Pancasila in local finance accountability is an accountability which is fair to all the people in the life of nationhood and statehood, not only for certain groups, especially thosepolitical groups so that it cannot be enjoyed or viewed good by the society. This is inline with the main objective of the regional autonomy: to improve society's welfare.

Thus, local finance accountability must involve all society in its process[6] which allows them to assess whether the local finance accountability has justice value and benefits the people. This is due to the fact that current mechanism for local finance accountability has not yet provided certainty about society's role in providing an evaluation. 
The accountable, real and extensive policy of granting regional autonomy to the regions makes up a strategic step in two things. First, regional autonomy is the answer to local problems of Indonesian nation in the forms of threats, namely (1) nation's disintegration; (2) worsening poverty; (3) inequality in development; (4) low quality of the people's life; and (5) low Human Resources Development. Second, regional autonomy is a strategic step of Indonesian nation to welcome economic globalization era by strengthening its local economy [7].

So, implementing Pancasila justice value in the local financial accountability will create a humanist relationship between the government and the society. The humanist relationship will have a positive impact on the relationship among the people, because the people will feel that they are treated fairly in the administration of the local government and in the local financial management.

\subsection{Relationship amongst political institutions that ignores justice value of Pancasila in local finance accountability.}

Pancasila as an ideology of the political life is reflected in its role and function which serves as the cornerstone and at the same time as the goal of the Indonesia's political life. The problem in the ongoing process of political development lies in how to transform the existing political system into a reliable Pancasilademocracy political system [8].

Relating the Head of Region's accountability to local finance in the form of a Finance Accountability Report (LKPJ)is associated with the relations of power between the Head of Region and the Local Parliament. In this case, the Head of Region's accountability on local finance has a logical consequence, which is an obligation to submit the LKPJ to Local Parliament along with the results obtained, which consequently reduces the Head of Region's authority, due to the fact that Local Parliament with their oversight rights, including: right of interpellation, inquiry right, and right to petition allow them to inquire about or even investigate the LKPJ.

In this case, political interest in fact deals extensively with power and interests [9]. This kind of settlement will not be realized if it fails to adhere to political ethics, as the objective of good political ethics is to promote freedom and build fair and just institutions[10]. The definition of this political ethics is to help analyzing a correlation between individual action, collective action and the existing structures.

Simply, the main problem the Head of Region facing in the local finance accountability is not the democracy, but on a number of democracy ethics that are ignored by political elites, or broadly speaking, all parties should consider the people's prosperity in running Local Governance.

Aware of such condition, local finance accountability should be viewed from the perspective of democracy that grants extensive, real, and accountable regional autonomy, in addition to the aspect of harmonious relationship between the Head of Region and the Local Parliament. This is not separable from the functions of the Local Parliament in its capacity as a caretaker and provider of society's aspirations and its oversight function towards local government administration and regional development, as well as a partner of the Head of Region in the similar level in terms of formulating policies on various emerged problems.

Therefore, if the political elites in a region consider that regional financial accountability as a reality of interest, then Pancasila justice value cannot be applied. Consequently, it will have a negative impact on the people's life. Because the main objective of implementing regional autonomy is to bring prosperity to the people, one of which is achieved through a good regional financial management. 
Therefore, the Local Parliament's oversight on local finance accountability report does not necessarily hamper the effectiveness of local government administration, but is aimed at creating a powerful and more productive government, by still promoting the spirit of a harmonious and open cooperation, and seeking to base all policies taken on laws should be accountable and provide justice value for the society.

\section{CONCLUSION}

The current mechanism of the local government official accountability on local finance is still based on the formal procedural relation amongst political institutions in the region which ignores justice value of Pancasila. Hence, it fails to achieve regional autonomy objectives which one of them is to further expand local society's welfare, and thereby it should be a reinforcement against local finance accountability mechanisms by involving societal groups as the testing instrument to examine whether a local finance administration is in accordance with the regional autonomy objectives or not. Thus, the local finance accountability can provide a justice value as mandated in the fifth principle of Pancasila, so as to establish a humanistic relationship between the Government and the people, which in turn will create a good society.

\section{REFERENCES}

[1] M. Nasution, Pertanggungjawaban Gubernur dalam Negara Kesatuan Indonesia. Medan: Sofmedia, 2011.

[2] M. S. Lubis, Sistem Nasional. Medan: Universitas Sumatera Utara Press, 1988.

[3] M. S. Lubis, Ilmu Pengetahuan Perundang-Undangan. Bandung: Mandar Maju, 2009.

[4] C. S. T. Kansil, Empat Pilar Berbangsa dan Bernegara. Rineka Cipta, 2011.

[5] D. Darmodiharjo, N. Dekker, and A. G. Pringgodigdo, Santiaji Pancasila. Surabaya: Usaha Nasional, 1991.

[6] Safi', I. Winarwati, and E. Rusdiana, "Partisipasi Masyarakat dalam Perencanaan dan Penganggaran APBD di Kabupaten Bangkalan,” Yust. J. Huk., vol. 4, no. 2, Aug. 2015.

[7] A. Halim and I. Mujib, Problem Desentralisasi dan Perimbangan Keuangan Pemerintah Pusat dan Daerah. Yogyakarta: Sekolah Pasca Sarjana UGM, 2009.

[8] O. Oesman and Alfian, Pancasila Sebagai Ideologi dalam Berbagai Bidang Kehidupan Bermasyarakat, Berbangsa dan Bernegara. Jakarta: BP-7 Pusat, 1991.

[9] S. Wasistiono and O. Riyani, Etika Hubungan Legislatif-Eksekutif dalam Pelaksanaan Otonomi Daerah. Bandung: Fokusmedia, 2003.

[10] R. Hariantati, "Etika Politik dalam Negara Demokrasi," J. Demokr., vol. 2, no. 1, pp. 57-68, 2003. 